\title{
Kualitas Air dan Struktur Komunitas Plankton di Perairan Pantai Lovina Kabupaten Buleleng Provinsi Bali
}

\author{
Irene Yolanda Br Ginting a*, I Wayan Restu a, Dewa Ayu Angga Pebriani a \\ a Program Studi Manajemen Sumberdaya Perairan, Fakultas Kelautan dan Perikanan, Universitas Udayana Jimbaran, Badung, Bali - Indonesia \\ * Penulis koresponden. Tel.: +62-81236300896 \\ Alamat e-mail: ireneyolanda80@yahoo.com
}

Diterima (received) 27 September 2017; disetujui (accepted) 28 Agustus 2018; tersedia secara online (available online) 30 Agustus 2018

\begin{abstract}
Lovina Beach is one of the beaches visited by many foreign and domestic tourists. Lovina Beach has a tourism spot and a vast area of marine biota cultivation. Life of biota in the waters of Lovina Beach is affected by conditions of beach waters. The research purpose was to know the correlation between waters quality and plankton in Lovina Beach by using observation method. The research was done on February until March 2017. Species of fitoplankton species from all three stations was dominated by Lyngbya sp. with abundance of $78 \mathrm{ind} / \mathrm{l}$. The average value of the phytoplankton diversity index found was 1.7706 . The average value of phytoplankton uniformity index is 0.9882 while the value of phytoplankton dominance index is 0.1737 . The average value of the zooplankton diversity index found is 1.7311 . The average value of the zooplankton uniformity index is 0.8896 while the zooplankton dominance index value is 0.2125 . The result of the measurement of water quality is temperature parameter in Lovina Beach ranged from 27.6 - 28.9 0C, brightness ranged between 4.7 - $6 \mathrm{~m}$, salinity of 25.3 - 27 ppt, DO (Dissolved Oxygen) ranged between $4-4,7 \mathrm{Mg} / \mathrm{L}$, the $\mathrm{pH}$ ranged from 8.5 to 8.6 , the nitrate ranged from $0.0081-00087 \mathrm{Mg} / \mathrm{L}$ and the phosphate ranged from 0.016 to 0.027 $\mathrm{Mg} / \mathrm{L}$. So, it can be concluded that the waters of Lovina Beach has the highest abundance of plankton that is the type of zooplankton, the level of plankton community structure in Lovina Beach waters is moderate.ppt, DO (Dissolved Oxygen) $4-4,3 \mathrm{Mg} / \mathrm{l}$, pH 8,5 - 8,6, nitrate $0,0081-0,0087 \mathrm{Mg} / \mathrm{l}$ and phosphate $0,016-0,027 \mathrm{Mg} / \mathrm{L}$. The structure of plankton community in Lovina coastal according of phytoplankton abundance categorized in oligotropic, while according of zooplankton abundance categorized in moderate (mesotropic).
\end{abstract}

Keywords: community structure; Lovina Beach; water quality

\begin{abstract}
Abstrak
Pantai Lovina merupakan salah satu pantai yang banyak dikunjungi wisatawan luar negeri maupun dalam negeri. Pantai Lovina memiliki pantai wisata dan area budidaya biota laut yang sangat luas. Kehidupan biota di perairan Pantai Lovina dipengaruhi oleh kondisi perairan pantai. Tujuan penelitian ini untuk mengetahui hubungan antara kualitas perairan dengan kehidupan plankton di Pantai Lovina dengan menggunakan metode observasi. Penelitian dilaksanakan pada Bulan Februari sampai Maret 2017. Spesies fitoplankton yang mendominasi dari ketiga stasiun adalah spesies Lyngbya sp. dengan kelimpahan total 78 ind/l. Spesies zooplankton yang dominan dari ketiga stasiun adalah spesies Copepoda sp. dengan kelimpahan 149 ind/l. Nilai rata-rata indeks keanekaragaman fitoplankton yang ditemukan bernilai 1,7706. Nilai rata-rata indeks keseragaman fitoplankton bernilai 0,9882 sedangkan nilai indeks dominansi fitoplankton bernilai 0,1737. Nilai rata-rata indeks keseragaman zooplankton bernilai 0,8896 sedangkan nilai indeks dominansi zooplankton bernilai 0,2125. Nilai Rata-rata indeks keanekaragaman zooplankton yang ditemukan bernilai 1,7311. Hasil dari pengukuran kualitas perairan yaitu parameter suhu di Pantai Lovina berkisar 27,6 - 28,9 0C, kecerahan berkisar antara 4,7-6 m, salinitas berkisar 25,3 - 27 ppt, DO (Dissolved Oxygen) berkisar antara $4-4,7 \mathrm{Mg} / \mathrm{L}$, $\mathrm{pH}$ berkisar antara 8,5-8,6, nitrat berkisar antara 0,0081-0,0087 Mg/L dan fosfat berkisar antara $0.016-0.027 \mathrm{Mg} / \mathrm{L}$. Tingkat struktur komunitas plankton di perairan Pantai Lovina berdasarkan kelimpahan fitoplankton tergolong dalam oligotrofik sedangkan berdasarkan kelimpahan zooplankton tergolong kategori sedang (mesotrofik).
\end{abstract}

Kata Kunci: kualitas air; Pantai Lovina; struktur komunitas 


\section{Pendahuluan}

Indonesia merupakan negara kepulauan terbesar di dunia yang memiliki kurang lebih 95,161 pulau dengan wilayah perairan sekitar 5,9 juta $\mathrm{km}^{2}$ atau sekitar 70 - 75\% (Lasabuda, 2013). Indonesia memiliki sumberdaya alam yang sangat melimpah dan berpotensi untuk dikembangkan terutama perairannya, namun dalam pemanfaatannya perlu diperhatikan kelestariannya agar berkelanjutan. Selain itu, air merupakan sumberdaya alam yang diperlukan oleh semua mahluk hidup di bumi, sehingga pemanfaatan air tersebut harus terlaksana dengan sangat baik untuk membangun suatu ekosistem yang sempurna (Resosudarmo dkk., 2002), salah satu pulau yang memiliki potensi keindahan dan kekayaan hayati di pesisir dan lautannya adalah pulau Bali.

Bali merupakan destinasi wisata paling popular di Indonesia dan salah satu pulau yang mempunyai garis pantai sangat luas yang menjadikan Pulau Bali menjadi daerah wisata karena keunikan pantai tersebut. Salah satunya adalah Pantai Lovina yang terletak di Kabupaten Buleleng. Pantai Lovina menjadi salah satu tujuan dari wisatawan karena keunikan dari pantai tersebut, dengan adanya atraksi lumba-lumba, snorkeling, diving dan lainlain. Perkembangan Pantai Lovina menjadi kawasan wisata akan mempengaruhi kualitas perairan di pantai tersebut (Mustika, 2013).

Kualitas perairan Pantai Lovina dapat dipantau dengan pengukuran menggunakan parameter fisika seperti suhu, kecerahan; parameter kimia seperti salinitas, DO, pH, Nitrat dan Fosfat; dan paremeter biologinya seperti keanekaragaman dan kelimpahan plankton. Plankton merupakan pengujian yang sering dilakukan untuk mengetahui kondisi suatu perairan karena plankton dapat digunakan sebagai bioindikator suatu perairan. Plankton merupakan organisme yang hidup mengapung dan pergerakannya tergantung pada arus (Usman dkk., 2013). Fitoplankton berperan sangat penting dalam suatu perairan, yaitu menjadi produsen primer pada rantai makanan dan sebagai parameter kesuburan perairan. Kelimpahan Fitoplankton dalam suatu perairan dapat dihubungkan dengan kesuburan suatu perairan tersebut karena dapat mengubah zat anorganik menjadi organik melalui proses fotosintesis (Arifin, 2009). Zooplankton juga dapat dijadikan sebagai indikator kesuburan perairan karena zooplankton berperan sebagai agen transfer energi dan indikator dari keberadaan fitoplankton (Ruga dkk., 2014).

Secara umum masalah yang berhubungan dengan daerah wisata adalah terjadinya gangguan ekosistem pantai karena kegiatan wisata yang ada, sehingga dikhawatirkan dapat memberikan dampak terhadap biota yang ada di Pantai Lovina, selain itu kegiatan wisata di Pantai Lovina akan mengakibatkan degradasi ekosistem laut serta perubahan kualitas air yang signifikan.

Tujuan dari penelitian ini adalah untuk mengetahui kualitas dan struktur komunitas plankton di perairan Pantai Lovina.

\section{Metode Penelitian}

\subsection{Waktu dan Lokasi Penelitian}

Penelitian ini dilakukan pada bulan Februari 2017 sampai Maret 2017 di Pantai Lovina Kalibukbuk Bali. Penelitian mengenai kualitas air dan struktur komunitas plankton dilaksanakan di perairan Pantai Lovina Kalibukbuk Provinsi Bali. Pengambilan sampel dilakukan pada 3 stasiun yaitu: 1) area pemukiman warga, 2) area wisata dan jalur transportasi kapal menuju laut dan 3) area hutan atau minim aktifitas. Lokasi penelitian dan stasiun pengambilan sampel kualitas air dan plankton menggunakan software Quantum GIS dan Google Earth (Alfianto, 2013) dapat dilihat pada Gambar 1.

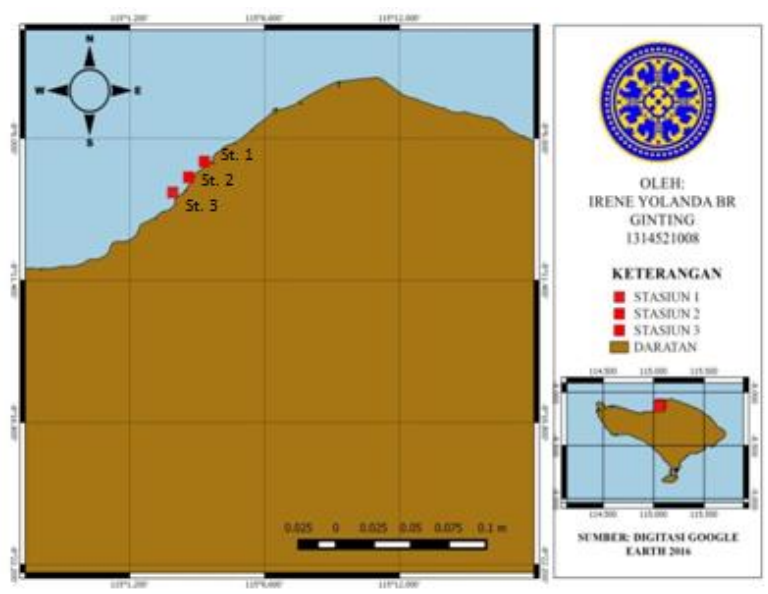

Gambar 1. Peta Lokasi Penelitian

\subsection{Alat dan Bahan}

Alat dan bahan merupakan penunjang penelitian pengambilan sampel. Alat dan bahan yang digunakan dalam penelitian ini meliputi alat tulis, 
plankton net, water sampler, ember, botol sampel, kertas label, sedgwick rafter, pipet tetes, tissue, mikroskop, opti lab, laptop, buku identifikasi plankton, GPS (Geographycal Positioning System), $\mathrm{pH}$ pen, termometer, DO meter, refrakto meter, secchi disk, meteran, coldbox, kamera, lugol 5\%, formalin $4 \%$, aquades, air sampel.

\subsection{Prosedur Penelitian}

\subsubsection{Penentuan stasiun}

Penentuan lokasi penelitian dilakukan dengan menggunakan metode umum yaitu metode observasi. Observasi adalah teknik pengumpulan data dengan melakukan pengamatan langsung pada objek kajian, dengan membagi tiga stasiun 1 (area rumah warga) satasiun 2 (area wisata) dan stasiun 3 (area hutan).

\subsubsection{Pengambilan sampel}

Pengambilan sampel plankton dilakukan dengan cara menyaring air laut sebanyak 30 liter pada setiap titik menggunakan plankton net berukuran 40 чm untuk fitoplankton dan plankton net berukuran 125 чm untuk zooplankton. Pengambilan sampel plankton plankton net yang berukuran 125 чm, sedangkian zooplankton akan diambil dengan water sampler dan menggunakan plankton net berukuran 40 чm. Sampel yang sudah didapat selanjutnya dimasukkan ke dalam botol sampel yang sudah tersedia, dan diberi warna dengan lugol 5\% menggunakan pipet tetes dan diawetkan dengan formalin 4\% (Wahyudiati, 2017).

Sampel yang sudah diberi keterangan dengan kertas label disimpan di dalam coolbox dan diberi es (Sihombing et al., 2017). Sampel diteliti di Laboratorium Perikanan dan diidentifikasi sesuai dengan buku identifikasi plankton A Guide to Common Gulf of Marine Phytoplankton, Coastal Plankton Photo Guide for European Seas.

\subsubsection{Parameter Kualitas Air}

Pengambilan sampel parameter kualitas air yang diukur meliputi parameter fisika yaitu suhu dan kecerahan sedangkan parameter kimia yaitu salinitas, DO, pH, nitrat dan fosfat. Untuk paremeter nitrat dan fosfat diukur secara exsitu, sedangkan paremeter lainnya akan diukur secara insitu.

\subsection{Analisis Data}

\subsubsection{Kelimpahan Plankton}

Perhitungan kelimpahan plankton per liter dilakukan dengan menggunakan rumus (APHA, 2005), yaitu:

$$
N=n \times \frac{A}{B} \times \frac{C}{D} \times \frac{1}{E}
$$

dimana A adalah jumlah kotak pada Sedgwick rafter (1000 kotak); B adalah jumlah kotak yang diamati (1000 kotak); C adalah volume air sampel yang tersaring $(\mathrm{ml})$; D adalah volume air sampel yang diamati (ml); E adalah volume air yang disaring (1); $\mathrm{N}$ adalah kelimpahan (sel/1); dan $\mathrm{n}$ adalah jumlah Individu per lapang pandang, krerteria kesuburan perairan berdasarkan fitoplankton terdapat pada Tabel 1 sedangkan berdasarkan zooplankton terdapat pada Tabel 2 .

Tabel 1

Kreteria Kesuburan Perairan Berdasarkan Kelimpahan Fitoplankton

\begin{tabular}{ccc}
\hline Perairan & $\begin{array}{c}\text { Tingkat } \\
\text { Kesuburan }\end{array}$ & $\begin{array}{c}\text { Kelimpahan } \\
\text { Fitoplankton (ind/I) }\end{array}$ \\
\hline Oligotropik & Rendah & $0-2000$ \\
Mesotropik & Sedang & $2000-15000$ \\
Eutropik & Tinggi & $>15000$ \\
\hline
\end{tabular}

Tabel 2

Kreteria Kesuburan Perairan Berdasarkan Kelimpahan Fitoplankton

\begin{tabular}{ccc}
\hline Perairan & $\begin{array}{c}\text { Tingkat } \\
\text { Kesuburan }\end{array}$ & $\begin{array}{c}\text { Kelimpahan } \\
\text { Zooplankton (ind/I) }\end{array}$ \\
\hline Oligotropik & Rendah & 1 \\
Mesotropik & Sedang & $1-500$ \\
Eutropik & Tinggi & $>500$ \\
\hline
\end{tabular}

\subsubsection{Indeks Keanekaragaman}

Indeks keanekaragaman jenis plankton adalah Gambaran secara matematik agar mempermudah analisis informasi mengenai jenis dan jumlah organisme. Indeks keanekaragaman plankton dihitung menggunakan indeks Shannon-Wienar (Setiawan, 2009):

$$
H^{\prime}=-\sum_{i=1}^{s} p i \ln p i
$$

dimana $\mathrm{H}^{\prime}$ adalah indeks keanekaragaman jenis; "Pi" adalah ni/N; ni adalah kelimpahan jenis pada 
peringkat ke-i; dan $\mathrm{N}$ adalah kelimpahan total, sedangkan untuk kreteria pencemaran berdasarkan keanekaragaman plankton terlihat pada Tabel 3.

Tabel 3

Kreteria Pencemaran Perairan

\begin{tabular}{ccl}
\hline No & Kreteria & \multicolumn{1}{c}{ Keterangan } \\
\hline 1 & $\mathrm{H}^{\prime}<1$ & $\begin{array}{l}\text { Komunitas biota tidak stabil atau } \\
\text { kualitas air tercemar berat }\end{array}$ \\
2 & $1<\mathrm{H}^{\prime}<3$ & $\begin{array}{l}\text { Stabilitas komunitas biota sedang } \\
\text { atau kualitas air tercemar sedang }\end{array}$ \\
3 & $\mathrm{H}^{\prime}>3$ & $\begin{array}{l}\text { Stabilitas komunitas biota dalam } \\
\text { kondisi (stabil) atau kualitas air } \\
\text { bersih }\end{array}$ \\
& &
\end{tabular}

\subsubsection{Indeks Keseragaman}

Sebaran masing-masing organism dapat ditentukan dengan membandingkan nilai indeks keanekaragaman dengan nilai maksimumnya, adapun rumus untuk indeks keseragaman yaitu (Fajri, 2013):

$$
E=\frac{H^{\prime}}{\text { Hmaks }}
$$

dimana $\mathrm{E}$ adalah indeks keseragaman; $\mathrm{H}^{\prime}$ indeks keanekaragaman; Hmaks adalah ln S; dan S adalah jumlah spesies.

Dengan perbandingan nilai E antara angka $0-1$. Jadi semakin kecil nilai untuk E maka semakin kecil juga kemungkinan keseragaman suatu populasi atau penyebaran tiap genus tidak sama dan kemungkinan ada yang mendominansi. Sebaliknya jika nilai untuk E tinggi maka keseragaman dapat dikatakan relative sama.

\subsubsection{Indeks Dominansi}

Indeks Dominansi tersebut digunakan untuk melihat adanya dominansi oleh jenis tertentu pada populasi plankton di pantai. Adapun rumus dari indeks domunansi oleh (Odum, 1996) adalah:

$$
D=\sum_{i=1}^{s}\left[\frac{n i}{N}\right]^{2}
$$

dimana D adalah indeks dominansi; ni adalah jumlah individu jenis ke-i; $\mathrm{N}$ adalah jumlah total individu; dan s adala jumlah genus.
Kondisi komunitas biota berdasarkan indeks dominansi dapat digolongkan sebagai berikut: $\mathrm{D}<$ $0,4=$ Dominansi populasi rendah, yang berarti tidak terdapat spesies yang mendominansi atau struktur komunitas dalam keadaan stabil. $\mathrm{D}>0,6=$ Dominansi populasi tinggi, yang berarti terdapat spesies yang mendominansi atau struktur komunitas dalam keadaan labil, karena tekanan ekologis.

\section{Hasil dan Pembahasan}

\subsection{Parameter Kualitas Air}

Parameter kualitas perairan di Pantai Lovina mengalami perubahan yang tidak terlalu berbeda. Paremeter yang diukur pada saat penelitian yaitu fisika dan kimia perairan. Tabel 4 menjelaskan paremeter fisika pada saat pengembilan sampel selama penelitian.

Tabel 4

Paremeter kimia fisika kualitas air

\begin{tabular}{clccc}
\hline \multirow{2}{*}{ NO } & \multirow{2}{*}{ Parameter } & \multicolumn{3}{c}{ Stasiun } \\
\cline { 3 - 5 } & & 1 & 2 & 3 \\
\hline 1 & $\mathrm{pH}$ & 8,53 & 8,5 & 8,63 \\
2 & DO $(\mathrm{mg} / \mathrm{l})$ & 4,43 & 4 & 4,7 \\
3 & Suhu $\left({ }^{\circ} \mathrm{C}\right)$ & 27,5 & 28,8 & 28,9 \\
4 & Kecerahan (m) & 4,6 & 5,9 & 5,1 \\
5 & Salinitas (ppt) & 25,3 & 27 & 26 \\
6 & Nitrat (mg/l) & 0,0086 & 0,0083 & 0,008 \\
7 & Fosfat (mg/l) & 0,076 & 0,027 & 0,065 \\
\hline
\end{tabular}

Berdasarkan hasil penelitian, diperoleh nilai rata-rata parameter kualitas perairan suhu di perairan Pantai Lovina berkisar 27,6 - 28,9 0C, nilai rata-rata parameter kecerahan perairan berkisar 4,7 $-6 \mathrm{~m}$, nilai salinitas yaitu berkisar $25,3-27 \mathrm{ppt}$, nilai DO (Dissolved Oxygen) berkisar antara $4-4,7 \mathrm{mg} / 1$ (Ulqodri, 2010) untuk nilai pH berkisar 8,5-8,6, sedangkan untuk kualitas perairan parameter kimia yaitu nitrat mempunyai nilai rata-rata berkisar $0,0081-0,0087 \mathrm{mg} / \mathrm{l}$, fosfat bernilai ratarata 0,016 - 0,027. Parameter fisika dan kimia perairan seperti suhu, kecerahan, salinitas, $\mathrm{DO}, \mathrm{pH}$, nitrat dan fosfat juga mempengaruhi pertumbuhan dan perkembangan fitoplankton. Nilai suhu dari hasil pengukuran memiliki nilai berkisar 27,6 0C 29,8 0C, dimana suhu yang sesuai dengan pertumbuhan fitoplankton adalah 20 OC - 30 OC (Kadir dkk., 2015). Jadi untuk nilai suhu yang di 
temukan di perairan Pantai Lovina adalah sesuai untuk pertumbuhan dan perkembangan fitoplankton.

Nilai salinitas pada saat penelitian di perairan Pantai Lovina memiliki nilai berkisar 25,3-27 ppt, nilai tersebut menyatakan bahwa salinitas di perairan Pantai Lovina cendrung normal untuk kehidupan plankton.

Oksigen terlarut dalam air sangat penting untuk kelangsungan hidup organisme laut. Kandungan Dissolved Oxygen (DO) mempengaruhi keanekaragaman organisme perairan. Berdasarkan hasil pengamatan di Perairan Pantai Lovina kandungan DO berkisar $4-4,7 \mathrm{mg} / \mathrm{l}$, berdasarkan nilai tersebut $\mathrm{DO}$ tergolong rendah untuk habitat yang stabil dalam pertumbuhan dan perkembangan fitoplankton, hal tersebut merupakan salah satu penyebab rendahnya fitoplankton yang ditemukan pada perairan Pantai Lovina. DO minimum untuk kehidupan pertumbuhan dan perkembangan fitoplankton adalah $5 \mathrm{mg} / \mathrm{l}$, (Uiqodri, 2010). Nilai untuk parameter $\mathrm{pH}$ yang ditemukan di perairan Pantai Lovina pada saat penelitian memiliki nilai berkisar 8,5 sampai 8,6 , nilai $\mathrm{pH}$ yang ditemukan sesuai untuk pertumbuhan dan perkembangan hidup plankton. Hal tersebut didukung oleh pendapat Barus (2004) yang menyatakan bahwa nilai $\mathrm{pH}$ ideal bagi kehidupan organism aquatik termasuk plankton pada umumnya berkisar antara $7-8,6$. Dalam suatu perairan, keberadan nitrat dan fosfat diperlukan untuk memenuhi kebutuhan nutrisi fitoplankton, sehingga fitoplankton dapat menghasilkan energi. Keberadaan nitrat dan fosfat yang berlebihan dalam suatu perairan dapat menyebabkan terjadinya eutrofikasi (blooming algae). Nitrat dipengaruhi oleh limbah yang berasal dari kegiatan pertanian dan kegiatan industri, biasanya dipengaruhi oleh buangan yang asalnya dari kegiatan pertanian, kegiatan industri, dan bahan peledak.

Hasil pengujian kadar nitrat di perairan Pantai Lovina diperoleh nilai yang berkisar 0,0081 - 0,0087 $\mathrm{mg} / \mathrm{l}$. Nilai nitrat di perairan Pantai Lovina tergolong rendah, nilai nitrat sebesar 0,0081 - 0,0087 $\mathrm{mg} / \mathrm{l}$ tergolong dalam rendah (Oligotrofik). Hal tersebut sesuai dengan pendapat Suryanti (2015) yang mengatakan tingkat kesuburan perairan melalui kadar nitrat. Oligotrofik berkisar antara 0 $0,1 \mathrm{Mg} / \mathrm{L}$, mesotrofik $0,1-0,5 \mathrm{Mg} / \mathrm{L}$ dan eutrofik 0,5 - $1 \mathrm{Mg} / \mathrm{L}$. Fosfat merupakan unsur hara penting dalam pertukaran energi yang dibutuhkan organisme akuatik dalam jumlah yang optimal yaitu $\pm 0,015 \mathrm{mg} / \mathrm{l}$, sehingga fosfat dikatakan sebagai faktor pembatas bagi pertumbuhan organisme. Nilai fosfat yang diperoleh dari perairan Pantai Lovina berkisar antara 0,016 - 0,027 $\mathrm{mg} / \mathrm{l}$ dan merupakan kadar yang optimum bagi pertumbuhan dan perkembangan kehidupan plankton. Hal tersebut dibuktikan dari Peraturan Gubernur Bali Nomor 16 Tahun 2016.

\subsection{Struktur Komunitas Fitoplankton}

Fitoplankton yang ditemukan saat penelitian di perairan Pantai Lovina Kalibukbuk sebanyak 6 jenis yaitu Coscinodiscus sp., Nitzchia sp., Bidulphia sp., Lyngbya sp., Pleurosigma sp. dan Ceratium sp. Kelimpahan fitoplankton pada setiap titik pengambilam sampel secara keseluruhan dari pengambilan ke I sampai pengambilan ke III di Pantai Lovina mempunyai nilai yang bervariasi terlihat pada Gambar 2. Nilai kelimpahan pada stasiun 1 memiliki nilai 103 ind/l sedangkan pada stasiun 2 memiliki nilai 149 ind/l dan untuk stasiun 3 memiliki nilai 96 ind/l.

Nilai kelimpahan fitoplankton tertinggi terdapat pada stasiun 2, dikarenakan sekitar stasiun tersebut terdapat kegiatan permukiman dan pariwisata. Kegiatan tersebut diperkirakan dapat menambah masukan unsur hara yang diperlukan fitoplankton untuk proses pertumbuhannya. Fitoplankton dapat tumbuh dan berkembang dengan baik apabila unsur hara yang di butuhkan tersedia dalam jumlah yang mencukupi. Unsur hara ataupun nilai nitrat dan fosfat di perairan Pantai Lovina mempunyai nilai berkisar untuk nitrat 0,0081-0,0087 dan untuk nilai fosfatnya sendiri adalah 0,016-0,027 dari hasil di atas unsur hara yang ada di perairan Pantai Lovina sesuai baku mutu kualitas untuk biota laut.

Kelimpahan total untuk Fitoplankton di perairan Pantai Lovina bernilai 346 ind/l. Jenis dan jumlah fitoplankton yang terdapat di perairan Pantai Lovina tergolong rendah, hal tersebut diduga karena cuaca pada saat penelitian mendung dan kondisi air di perairan Pantai Lovina bergelombang dan pasang. Hal tersebut dapat didukung oleh pendapat Nontji (1987) yang menyatakan bahwa Desember merupakan awal dari musim barat Desember-Februari dimana suhu turun mencapai minimum dan bertepatan pula dengan adanya angin yang kuat dan curah hujan yang tinggi. Penelitian dilaksanakan pada bulan Februari - Maret. 


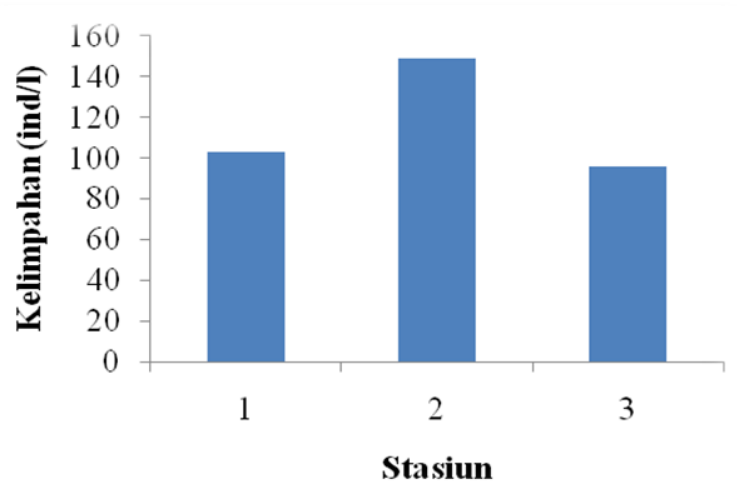

Gambar 2. Kelimpahan Fitoplankton

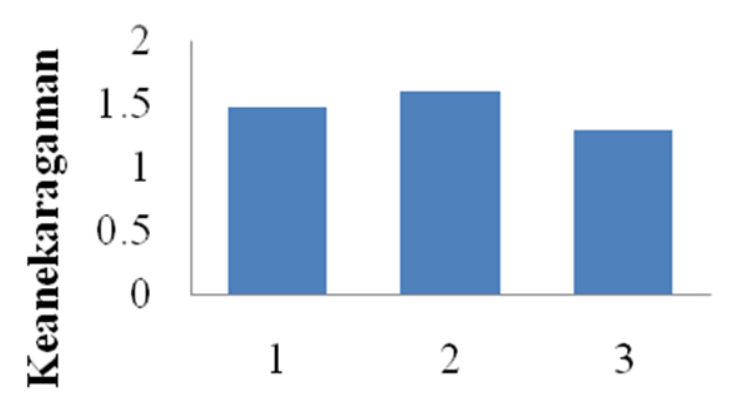

Stasiun

Gambar 3. Indeks Keanekaragaman fitoplankton

Nilai Indeks keanekaragaman $\left(\mathrm{H}^{\prime}\right)$ fitoplankton memiliki kisaran dari 1,2972 - 1,6029 (Gambar 3). Nilai total indreks keanekaragaman fitoplankton tersebut termasuk dalam katagori keanekaragaman yang sedang, hal tersebut didukung oleh pernyataan Shannon-Wienar, 1949 dalam Setiawan (2009) yang menyatakan bahwa keanekaragaman fitoplankton yang sedang memiliki nilai $1<\mathrm{H}^{\prime}<3$. Keanekeragaman fitoplankton Di Pantai Lovina tergolong dalam keanekaragaman yang sedang.

Indeks keseragaman (E) fitoplankton di perairan Pantai Lovina memiliki nilai yang berkisar antara 0,7240 - 0,8946 (Gambar 4) dari nilai tersebut keseragaman setiap jenis fitoplankton merata, hal tersebut sesuai dengan pendapat Fajri (2013) yang menyatakan bahwa dengan perbandingan nilai $\mathrm{E}$ antara angka 0 - 1 . Jadi semakin kecil nilai untuk $E$ maka semakin kecil juga kemungkinan keseragaman suatu populasi atau penyebaran tiap genus tidak sama dan kemungkinan ada yang mendominansi. Sebaliknya jika nilai untuk E tinggi maka keseragamn dapat dikatakan relative sama.

Indeks dominansi (D) fitoplankton di perairan Pantai Lovina memiliki nilai berkisar antara 0,2026
- 0,2975 (Gambar 5). Nilai indeks domonansi tersebut tergolong dalam dominansi yang rendah, dimana tidak ada satu spesies yang mendominansi atau setiap jenis fitoplankton seimbang atau dengan penyebaran yang merata di perairan Pantai Lovina. Hal tersebut didukung oleh pendapat Odum, 1996 yang mengatakan bahwa jika D $<0,4$ maka dominansi populasi rendah, yang berarti tidak terdapat spesies yang mendominansi atau struktur komunitas dalam keadaan stabil.

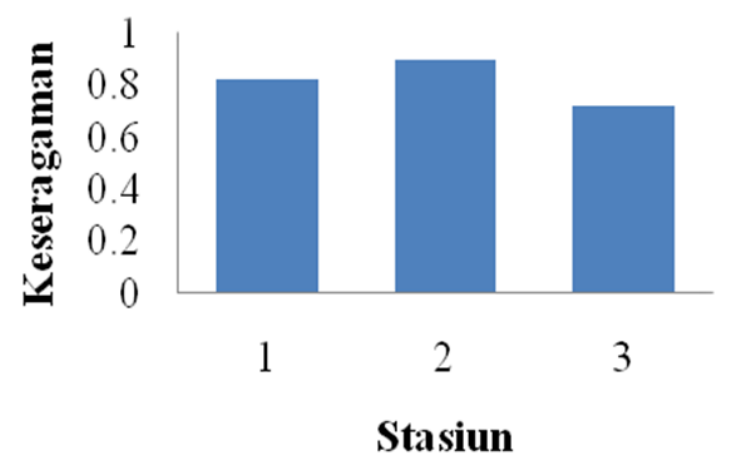

Gambar 4. Indeks Keseragaman fitoplankton

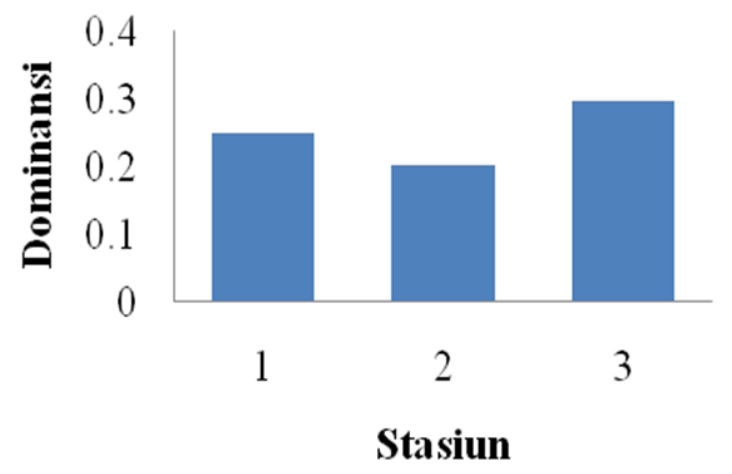

Gambar 5. Indeks Dominansi Fitoplankton

\subsection{Struktur Komunitas Zooplankton}

Zooplankton merupakan jenis plankton hewani yang berperan sebagai konsumen primer karena secara langsung memperoleh energi dari fitoplankton di perairan. Hasil penelitian yang dilakukan di perairan Pantai Lovina diperoleh 7 jenis yaitu Sagitta sp., Poecilochateus sp., Calanus sp., Copepoda sp., Naupli Crustasea sp., Larva Gastropod sp., dan Chameloa stiatula dacosta. Kelimpahan zooplankton pada setiap titik pengambilam sampel secara keseluruhan dari pengambilan ke I sampai pengambilan ke III di 
Pantai Lovina mempunyai nilai yang bervariasi. Nilai kelimpahan pada stasiun 1 memiliki nilai 117 ind/l sedangkan pada stasiun 2 memiliki nilai 135 ind/1 dan untuk stasiun 3 memiliki nilai 166 ind/l. Nilai kelimpahan zooplankton tertinggi terdapat pada stasiun 3 (Gambar 5), hal tersebut dikarenakan sekitar lingkungan stasiun 3 merupakan daerah yang sedikit pariwisata dan permukiman warga. Hal ini menyebabkan kualitas perairan yang mendukung pertumbuhan dan perkembangan zooplankton.

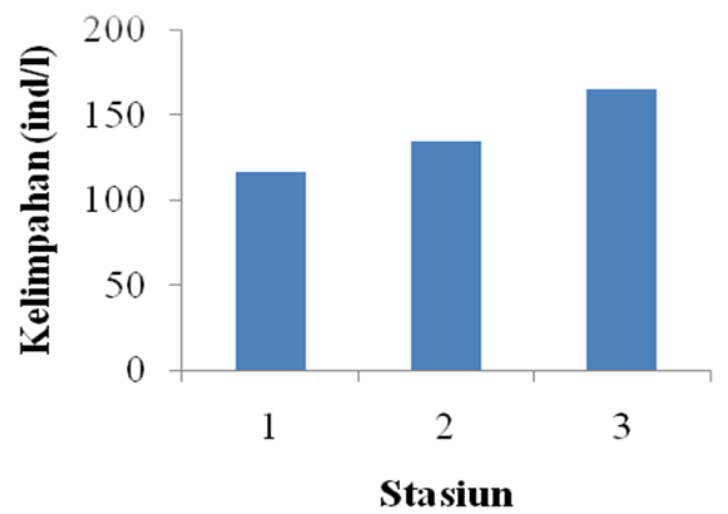

Gambar 5. Kelimpahan Zooplankton

Komunitas plankton di perairan Pantai Lovina sebagian besar didominansi oleh kelompok zooplankton. Keberadaan fitoplankton yang lebih rendah dibandingkan dengan keberadaan zooplankton diduga disebabkan oleh terjadinya proses peningkatan intensitas pemangsaan zooplankton terhadap fitoplankton hal tersebut didikung oleh pendapat Saito et al., (2009) yang menyatakan bahwa rendahnya kelimpahan fitoplankton dibandingkan dengan zooplankton dipengaruhi oleh faktor grazing atau pemangsaan zooplankton terhadap fitoplankton. Kesuburan dan kestabilan suatu perairan juga dapat dilihat dari keanekaragaman dan kelimpahan zooplankton (Rahayu dkk., 2013). Plankton yang paling banyak ditemukan adalah jenis zooplankton yaitu Copepod, hal tersebut didukung oleh pendapat Fitria (2011) yang menyatakan bahwa Copepod merupakan zooplankton yang paling dominan dan salah satu makan utama untuk ikan kecil di perairan laut dan menjadi salah satu jenis Copepoda yang memiliki jenis paling banyak. Sedangkan untuk plankton yang paling sedikit ditemukan adalah jenis Naupli Crustasea. Hal tersebut diduga karena adanya proses pemangsaan ikan terhadap Naupli Crustasea tersebut. Hal tersebut dikarenakan bahwa kebanyakan ikan termasuk dalam kategori karnivora yang buas dan rakus, pada saat larva sampai juvenil, makanan dari ikan tersebut adalah zooplankton dari jenis Rotifer, Acaria, Naupli Artemia, Naupli Crustasea dan jenis lainnya.

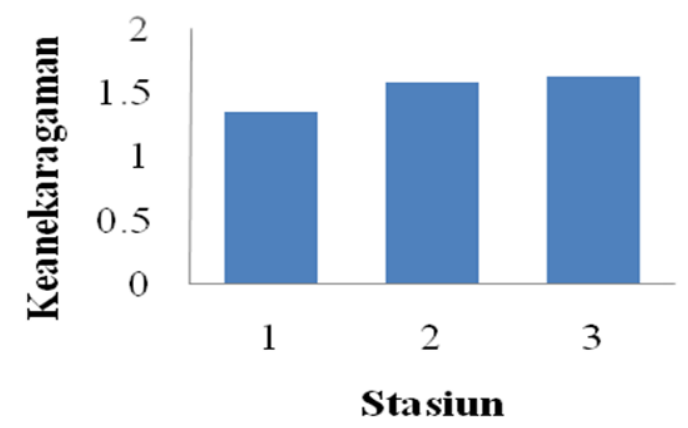

Gambar 6. Indeks Keanekaragaman Zooplankton

Nilai Indeks keanekaragaman $\left(\mathrm{H}^{\prime}\right)$ zooplankton memiliki kisaran dari 1,3558 - 1,6327 (Gambar 6). Nilai total indreks keanekaragaman zooplankton tersebut termasuk dalam katagori keanekaragaman yang sedang, hal tersebut didukung oleh pernyataan Setiawan (2009) yang menyatakan bahwa keanekaragaman zooplankton yang rendah memiliki nilai $1<\mathrm{H}^{\prime}<3$. Keanekeragaman zooplankton di perairan Pantai Lovina tergolong dalam keanekaragaman yang sedang.

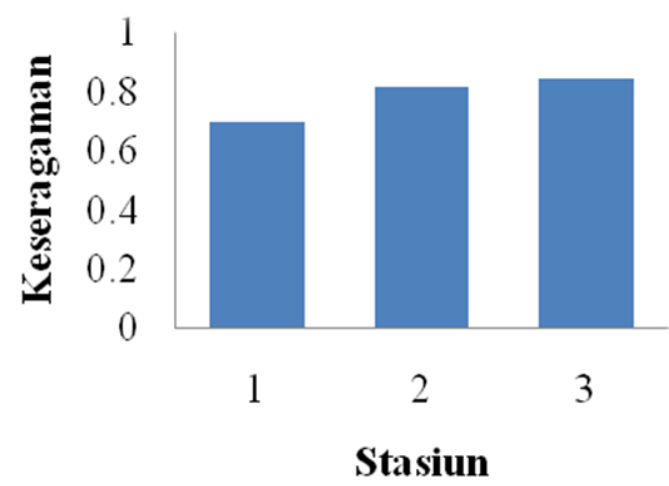

Gambar 7. Indeks Keseragaman Zooplankton

Indeks keseragaman (E) zooplankton di perairan Pantai Lovina memiliki nilai yang berkisar antara 0,6967 - 0,8390 (Gambar 7). Nilai indeks keseragaman zooplankton tersebut menyatakan bahwa keseragaman setiap jenis zooplankton dapat dikatakan merata. Hal tersebut sesuai dengan 
pendapat Fajri (2013) yang menyatakan bahwa dengan perbandingan nilai $\mathrm{E}$ antara angka $0-1$. Jadi semakin kecil nilai untuk E maka semakin kecil juga kemungkinan keseragaman suatu populasi atau penyebaran tiap genus tidak sama dan kemungkinan ada yang mendominansi. Sebaliknya jika nilai untuk E tinggi maka keseragamn dapat dikatakan relative sama.

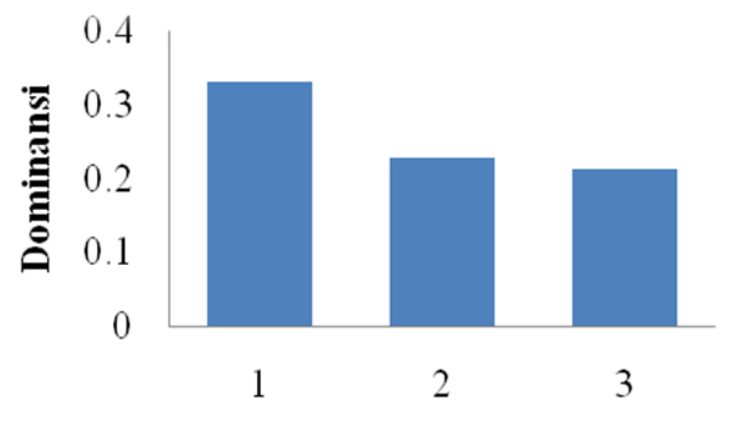

Stasiun

Gambar 8. Indeks Dominansi Zooplankton

Indeks dominansi (D) zooplankton di perairan Pantai Lovina memiliki nilai berkisar antara 0,2120 - 0,3290 (Gambar 8), nilai indeks domonansi tersebut tergolong dalam dominansi yang rendah, dimana tidak ada satu spesies yang mendominansi atau setiap jenis zooplankton seimbang atau dengan penyebaran yang merata di perairan Pantai Lovina. Hal tersebut didukung oleh pendapat Odum, 1996 yang mengatakan bahwa jika $\mathrm{D}<0,4$ maka dominansi populasi rendah, yang berarti tidak terdapat spesies yang mendominansi atau struktur komunitas dalam keadaan stabil.

Penelitian mengenai distribusi spasial dan struktur komunitas plankton yang dilakukan di daerah Teluk Penerusan, Desa Penjarakan, Kabupaten Buleleng (Damayanti, 2017). Penelitian dari 17 stasiun pengamatan yang diambil ditemukan 38 genus fitoplankton dan 7 Genus Zooplankton, perbedaan jumlah plankton yang ditemukan di perairan Pantai lovina diduga pengaruh dari kualitas perairan dan volume pengambilan sampel plankton.

Parameter kualitas air yang mendukung pertumbuhan zooplankton meliputi suhu, kecerahan, DO, pH. Nilai suhu yang di peroleh dari hasil pengukuran mendapatkan nilai berkisar 27,6 OC - 29,8 0C, dimana suhu yang sesuai dengan pertumbuhan zooplankton 25 0C - 30 0C (Kadir dkk, 2015). Jadi untuk nilai suhu yang di temukan di perairan Pantai Lovina adalah sesuai untuk pertumbuhan dan perkembangan zooplankton. Sedangkan untuk nilai paremeter kecerahan pada saat pengukuran di perairan Pantai Lovina memiliki nilai berkisar antara $4,7-6 \mathrm{~m}$, dikarenakan pada saat pengambilan sampel penelitian di perairan Pantai Lovina pada saat musim hujan, jadi terdapat air yang keruh dan bergelombang. Hal tersebut dapat didukung oleh pendapat Nontji (1987) yang menyatakan bahwa Desember merupakan awal dari musim barat (Desember-Februari) dimana suhu turun mencapai minimum dan bertepatan pula dengan adanya angin yang kuat dan curah hujan yang tinggi.

Kecerahan merupakan salah satu paremeter yang mempengaruhi keberadaan zooplankton dalam suatu perairan, karena diketahui bahwa sifat zooplankton sebagai organisme fototaksis negatif. Zooplankton melakukan gerakan naik dan turun secara harian (migrasi vertikal), dimana zooplankton akan naik ke permukaan pada malam hari dan turun ke lapisan perairan bawah pada siang hari. Hal tersebut sesuai dengan pernyataan Malida (2009) yang menyatakan bahwa zooplankton akan naik ke permukaan pada malam hari dan turun ke lapisan perairan bawah pada siang hari atau pada saat ada matahari. Hasil pengukuran kecerahan di Pantai Lovina adalah dengan rata-rata 4,7-6 m, tapi keadaan cuaca pada saat penelitian adalah mendung, jadi dapat diduga bahwa pada saat pengambilan sampel plankton yaitu zooplankton makan sampel berada di permukaan perairan.

Parameter DO yang dihitung pada saat penelitian mendapatkan nilai berkisar $4-4,7 \mathrm{Mg} / \mathrm{L}$, nilai DO tersebut lebih rendah untuk habitat yang stabil dalam pertumbuhan dan perkembangan zooplankton, hal tersebut menyebabkan zooplankton yang ditemukan pada perairan Pantai Lovina dalam kategori rendah. DO minimum untuk kehidupan pertumbuhan dan perkembangan zooplankton minimal $5 \mathrm{Mg} / \mathrm{L}$.

DO atau oksigen terlarut dibutuhkan oleh zooplankton untuk melakukan proses respirasi. Zooplankton cenderung akan berada pada daerah yang kaya akan oksigen, hal tersebut menyebabkan zooplankton pada stasiun 3 lebih banyak dari pada stasiun yang lainnya. Perhitungan parameter $\mathrm{pH}$ yang ditemukan di perairan Pantai Lovina pada saat penelitian memiliki nilai berkisar 8,5 sampai 8,6, nilai $\mathrm{pH}$ yang ditemukan sesuai untuk pertumbuhan dan perkembangan hidup plankton. 
Hal tersebut didukung oleh pendapat Barus 2004 yang menyatakan bahwa nilai $\mathrm{pH}$ ideal bagi kehidupan organism aquatik termasuk plankton pada umumnya berkisar antara $7-8,6$.

Kesuburan suatu perairan pada dasarnya mencerminkan tinggi rendahnya produktivitas perairan tersebut. Kesuburan perairan adalah kemampuan suatu perairan dalam menyediakan unsure hara yang dibutuhkan oleh organisme air terutama fitoplankton dalam proses pertumbuhan dan perkembangannya hal tersebut disampaikan oleh (Suryanto dan Umi, 2009). Tingkat kesuburan perairan dapat dilihat melalui kelimpahan plankton, sehingga Suryanto dan Umi (2009) membagi perairan berdasarkan kelimpahan plankton menjadi 3 bagian, yaitu: Oligotrofik yang tingkat kesuburannya rendah dengan kelimpahan fitoplankton yang berkisar antara $0-2000$ ind/l dan dengan kelimpahan zooplankton 1 ind/l, mesotrofik dengan tingkat kesuburan rendah dengan nilai kelimpahan fitoplankton yang berkisar 2000 - 15.000 ind/l dan kelimpahan zooplankton berkisar antara $1-500$ ind/1 dan yang terakhir kesuburan eutrofik dengan kelimpahan fitoplankton benilai $>15.000$ ind/l dengan kelimpahaan fitoplankton bernilai $>500$ ind/l.

Berdasarkan klasifikasi tersebut, perairan Pantai Lovina yang memiliki kelimpahan fitoplankton sebesar 346 ind/1 tergolong dalam kesuburan perairan Oligotrofik atau tingkat kesuburan yang rendah. Tetapi untuk kelimpahan zooplankton mempunyai nilai sebesar 418 ind/l merupakan perairan mesotrofik dengan tingkat kesuburan yang sedang.

\section{Simpulan}

Berdasarkan penelitian yang dilakukan mengenai analisis kualitas perairan dan plankton di Pantai Lovina maka dapat diambil kesimpulan beberapa hal sebagai berikut, yaitu Penilitian di Pantai Lovina mengenai data dasar mengenai kondisi kualitas air dari parameter fisikan dan kimia beracuana terhadap Peraturan Gubernur Bali Nomor 16 Tahun 2016. Kondisis kualiatas perairan di Pantai Lovina baik parameter fisika dan kimia masih sudah memenuhi standarat baku, kecuali DO. Selama penelitian di perairan Pantai Lovina maka diperoleh jenis - jenis fitoplankton sebanyak 6 jenis yaitu Coscinodiscus sp., Nitzchia sp., Bidulphia sp., Lyngbya sp., Pleurosigma sp., dan Ceratium sp. Jenis - jenis zooplankton sebanyak 7 jenis yaitu Sagitta sp., Poecilochateus sp., Calanus sp., Copepoda sp., Naupli Crustasea sp., Larva Gastropod sp., dan Chameloa striatula dacosta. Perairan Pantai Lovina yang memiliki kelimpahan fitoplankton tergolong dalam kesuburan perairan Oligotrofik atau tingkat kesuburan yang rendah. Tetapi untuk kelimpahan zooplankton merupakan perairan mesotrofik dengan tingkat kesuburan yang sedang.

\section{Daftar Pustaka}

Alifianto, F., Rodiyati, A., \& Brian, R. (2013). Peta Persebaran Porang (Amorphophallus muelleri Blume) Berdasarkan Topografi Wilayah di Malang Raya. Jurnal Biotropika, 1(2), 75-79.

American Public Health Association, American Water Works Association, Water Pollution Control Federation, \& Water Environment Federation. (1915). Standard methods for the examination of water and wastewater (Vol. 2). American Public Health Association.

Arifin, D. (2009). Distribusi Spasial dan Temporal Biomassa Fitoplankton (Klorofil-a) dan Keterkaitan dengan Kesuburan Perairan Estuari Sunagi Brantas, Jawa Timur. (Skripsi). Departemen Manajemen Sumberdaya Perairan Fakultas Perikanan dan Ilmu Kelautan Institut Pertanian Bogor.

Barus, T. A. (2004). Faktor-faktor lingkungan abiotik dan keanekaragaman plankton sebagai indikator kualitas perairan danau Toba. Jurnal Manusia dan Lingkungan, 11(2), 64-72.

Damayanti, N., M., D., Hendrawan, I., G., \& Faiqoh, E. (2017). Distribusi Spasial Dan Struktur Komunitas Plankton di Daerah Teluk Penerusan, Kabupaten Buleleng. Journal of Marine and Aquatic Sciences, 3(2), 191-203.

Fajri, N. (2013). Struktur Komunitas Makrozoobenthos di Perairan Pantai Kuwang Wae Kabupaten Lombok Timur. Jurnal Education, 8(2), 81-100.

Fitriya, N., Kaswadji, R., \& Mulyadi. (2011). Komposisi Copepoda di perairan Berau, Kalimantan Timur. Oseanologi dan Limnologi di Indonesia, 37(2), 355-368.

Kadir, M. A., Damar, A., \& Krisanti, M. (2015). Dinamika Spasial dan Temporal Struktur Komunitas Zooplankton di Teluk Jakarta. Jurnal Ilmu Pertanian Indonesia, 20(3), 247-256.

Lasabuda, R. (2013). Pembangunan Wilayah Pesisir Dan Lautan Dalam Perspektif Negara Kepulauan Republik Indonesia. Jurnal Ilmiah Plata, 1(2), 92-101.

Malida, H. S. (2009). Model Migrasi Zooplankton Secara Temporal Dengan Pendekatan Optik Laut Di Perairan Pulau Barrang Lompo, Makassar. Skripsi, Jurusan Ilmu Kelautan, FIKP Universitas Hasanuddin, Makassar. 
Mustika, P. L. K., Birtles, A., Everingham, Y., \& Marsh, H. (2013). The human dimensions of wildlife tourism in a developing country: Watching spinner dolphins at Lovina, Bali, Indonesia. Journal of Sustainable Tourism, 21(2), 229-251.

Nontji, A. (1987). Laut Nusantara. Penerbit Djambatan. Jakarta.

Odum. (1996). Dasar- dasar Ekologi. Edisi ketiga. Terjemahan: Samingan, T., Srigandono. Fundamentals of Ecology. Thrid Edition. Gadjah Mada University Press. Yogyakarta

Pemprov Bali. (2016). Peraturan Gubernur Bali Nomor 16 Tahun 2016 tentang Baku Mutu Lingkungan Hidup dan Kriteria Baku Kerusakan Lingkungan Hidup. Denpasar, Indonesia: Pemerintah Daerah Provinsi Bali.

Rahayu, S., Setyawati, T. R., \& Turnip, M. (2013). Struktur Komunitas Zooplankton di Muara Sungai Mempawah Kabupaten Pontianak Berdasarkan Pasang Surut Air Laut. Jurnal Protobiont, 2(2), 49-55.

Ruga, L., Langoy, M., Papu, A., \& Kolondam, B. (2014). Identifikasi Zooplankton di Perairan Pulau Bunaken Manado. Jurnal Mipa Unsrat Online, 3(2), 84-86.

Saito, T., Shimizu, I., Seki, J., \& Nagasawa, K. (2009). Relationship between zooplankton abundance and the early marine life history of juvenile chum salmon Oncorhynchus keta in eastern Hokkaido, Japan. Fisheries Science, 75(2), 303-316.

Setiawan, D. (2009). Studi Komunitas Makrozoobenthos di Perairan Hilir Sungai Lematang Sekitar Daerah
Pasar Bawah Kabupaten Lahat. Jurnal Penelitian Sains, 9(12-14), 67-72.

Sihombing, H. P., Hendrawan, I. G., \& Suteja, Y. (2018). Analisis Hubungan Kelimpahan Plankton di Permukaan Terhadap Hasil Tangkap Ikan Lemuru (Sardinella lemuru) di Selat Bali. Journal of Marine and Aquatic Sciences, 4(1), 151-161.

Suryanti, N. I., \& Purnomo, P. W (2015). Kesuburan Perairan Berdasarkan Nitrat, Fosfat, Dan Klorofil-A Di Perairan Ekosistem Terumbu Karang Pulau Karimunjawa. Diponegoro Journal Of Maquares, 4(2), 7581.

Suryanto, A. M. H., \& Umi, H. U. (2009). Pendugaan Status Trofik dengan Pendekatan Kelimpahan Fitoplankton dan Zooplankton di Waduk Sengguruh, Karangkates, Lahor, Wlingi Raya dan Wonorejo Jawa Timur. Jurnal Ilmiah Perikanan dan Kelautan, 1(1), 7-13.

Ulqodry, T. Z., Yulisman, Y., Syahdan, M., \& Santoso, S. (2010). Karakterisitik dan sebaran nitrat, fosfat, dan oksigen terlarut di perairan Karimunjawa Jawa Tengah. Jurnal Penelitian Sains, 13(1), 35-41.

Usman, M. S., Kusen, J. D., \& Rimper, J. R. (2013). Struktur Komunitas Plankton Di Perairan Pulau Bangka Kabupaten Minahasa Utara. Jurnal Pesisir Dan Laut Tropis, 2(1), 51-57.

Wahyudiati, N. W. D., Arthana, I. W., \& Kartika, A. R. G. (2017). Struktur Komunitas Zooplankton di Bendungan Telaga Tunjung, Kabupaten Tabanan-Bali. Journal of Marine and Aquatic Sciences, 3(1), 115-122.

(C) 2018 by the authors; licensee Udayana University, Indonesia. This article is an open access article distributed under the terms and conditions of the Creative Commons Attribution license (http://creativecommons.org/licenses/by/3.0/). 